\title{
Antimicrobial susceptibility of Clostridium difficile isolated from animals and humans in Brazil
}

\author{
Sensibilidade antimicrobiana de Clostridium difficile isoladas de animais e humanos no Brasil
}

\author{
Rodrigo Otávio Silveira Silva ${ }^{\mathrm{I} *}$ Carlos Augusto Oliveira Junior ${ }^{\mathrm{I}}$ Amanda Nádia Diniz \\ Guilherme Guerra Alves ${ }^{I}$ Roberto Maurício Carvalho Guedes ${ }^{I}$ Eduardo Garcia Vilela ${ }^{\text {II }}$ \\ Francisco Carlos Faria Lobato ${ }^{\mathrm{I}}$
}

\section{ABSTRACT}

The objective of this study was to evaluate antimicrobial susceptibility in Clostridium difficile strains isolated from animals and humans in Brazil. The 54 C. difficile strains used were isolated from stool samples from piglets $(n=16)$, dogs $(n=13)$, humans $(n=13)$, foals $(n=8)$ calves $(n=2)$, an ocelot $(n=1)$ and a maned wolf $(n=1)$. Antimicrobial susceptibility was determined using the serial plate agar dilution method for penicillin, florfenicol, oxytetracycline, erythromycin, vancomycin, metronidazole and tylosin. The $\mathrm{C}$. difficile strains assessed were susceptible to metronidazole and vancomycin. Florfenicol resistance was rarely observed; 52 (96.4\%) strains were sensitive to this antimicrobial. Five (9.3\%), five (9.3\%), 14 (25.9\%) and 20 (37.0\%) strains were resistant to oxytetracycline, penicillin, tylosin and erythromycin respectively.

Key words: nosocomial diarrhea, pseudomembranous colitis, resistance.

RESUMO

O objetivo do presente trabalho foi avaliar a sensibilidade antimicrobiana de estirpes de Clostridium difficile isoladas de animais e humanos no Brasil. Foram utilizados 54 estirpes de $\boldsymbol{C}$. difficile isoladas de fezes de leitões $(n=16)$, cães $(n=13)$, seres humanos $(n=13)$, potros $(n=8)$, bezerros $(n=2)$, jaguatirica $(n=1)$ e um lobo-guará $(n=1)$. A sensibilidade antimicrobiana foi determinada pelo método de diluição seriada em ágar para penicilina, florfenicol, oxitetraciclina, eritromicina, vancomicina, metronidazol e tilosina. Todos os isolados foram sensíveis ao metronidazol e á vancomicina. Resistência ao florfenicol foi rara, sendo que 52 (96,4\%) das estirpes foram sensíveis a esse antimicrobiano. Cinco (9,3\%), cinco (9,3\%), $14(25,9 \%)$ e 20 (37,0\%) foram resistentes a oxitetraciclina, penicilina, tilosina e eritromicina, respectivamente.

Palavras-chave: diarreia nosocomial, colite pseudomembranosa, resistência.

\section{INTRODUCTION}

Clostridium difficile is a Gram-positive, spore-forming bacillus responsible for most human antibiotic-associated diarrhea cases. The main risk factors associated to $\boldsymbol{C}$. difficile infection (CDI) in humans are age older than 65 , previous antibiotic therapy and prolonged hospitalization. An increase of the occurrence of community-acquired CDI, mainly in pregnant or puerperal women and children, has drawn attention to possible changes in the disease epidemiology (SILVA JÚNIOR, 2012).

In veterinary medicine, it produces diarrhea and colitis in several species and primarily affects domestic animals (SILVA et al., 2013a). However recently, its effects on wild species have been reported (BOJESEN et al., 2006; SILVA et al., 2013b). Similar to the human disease, C. difficile infections (CDIs) in animals are commonly associated with antimicrobial treatments (BÅVERUD, 2004; SONGER et al., 2009; HOPMAN et al., 2011; SILVA et al., 2012).

Recent studies have shown that isolates from human cases of pseudomembranous colitis caused by $\boldsymbol{C}$. difficile are genetically similar to strains isolated from domestic animals, which suggest that this disease could be zoonotic (JHUNG et al., 2008; NORMAN et al., 2011). Although C. difficile is a major cause of enteric disorders in humans and animals as well as a possible zoonotic agent, few studies have evaluated the antimicrobial susceptibility

'Escola de Veterinária, Universidade Federal de Minas Gerais (UFMG), Avenida Antônio Carlos, 6627, 31270-901, Belo Horizonte, MG,

Brasil. E-mail: rodrigo.otaviosilva@gmail.com. *Autor para correspondência.

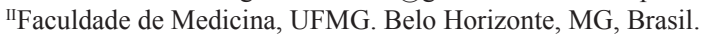


of $\boldsymbol{C}$. difficile strains in Brazil. Most current reports are not robust and are limited to human isolates. Thus, the objective of this study was to evaluate the antimicrobial susceptibility of $\boldsymbol{C}$. difficile strains isolated from animals and humans in Brazil.

\section{MATERIAL AND METHODS}

Fifty-four $C$. difficile strains isolated from piglets $(n=16), \operatorname{dogs}(n=13)$, humans $(n=13)$, foals $(n=8)$, calves $(n=2)$, an ocelot $(n=1)$ and a maned wolf $(n=1)$ were used in this study. Table 1 summarizes the species and strains included in this study as well as their clinical history. These isolates belong to the Clostridium strains library of the Veterinary School of Federal University of Minas Gerais (UFMG) and were isolated in previous published works (between 2009 and 2013) or ongoing projects (SILVA et al., 2011; SILVA et al., 2013b, Silva et al., 2013c; SILVA et al., 2013d). After isolation and confirmation of identity by a previous described multiplex PCR (SILVA et al., 2011), all strains were lyophilized and kept at $-20^{\circ} \mathrm{C}$ until reconstitution for this work.

The minimum inhibitory concentration (MIC) was determined using the serial agar dilution method as recommended by the Clinical and Laboratory Standards Institute (CLSI, 2011) and The European Committee on Antimicrobial
Susceptibility Testing (EUCAST, 2011). The following antimicrobials were tested: penicillin, florfenicol, oxytetracycline, erythromycin, vancomycin, metronidazole and tylosin. For an assay control, the reference specimen Bacterioides fragilis (ATCC 25285) was used. For the antimicrobials, the following concentrations were tested: $0.25,0.5,1.0$, 2.0, 4.0, 8.0, 16.0, 32.0, 64.0, 128.0 and 256.0 $\mu \mathrm{g}$ $\mathrm{ml}^{-1}$. Tests were performed on Brucella agar (Difco Laboratories, USA) supplemented with 5\% horse blood, hemin and vitamin K (CLSI, 2011).

\section{RESULTS}

The MIC results for the 54 C. difficile strains analyzed are in table 2. The strains were susceptible to metronidazole and vancomycin. Susceptibility to florfenicol and oxytetracycline was observed in $96.3 \%$ and $79.6 \%$ of the strains respectively. Five (9.3\%), five (9.3\%), 14 (25.9\%) and $20(37.0 \%)$ strains were resistant to oxytetracycline, penicillin, tylosin and erythromycin respectively.

\section{DISCUSSION}

The C. difficile strains assessed were susceptible to metronidazole and vancomycin, which are the antimicrobials commonly used to treat CDI

Table 1 - Number of Clostridium difficile strains used to evaluate antimicrobial susceptibility in each animal species and their clinical history. Tabelas para CR têm no máximo três linhas contínuas. As demais devem ser deletadas ou substituídas por linha tracejadas

\begin{tabular}{|c|c|c|c|}
\hline Species & Clinical history & Number of strains & Total \\
\hline \multirow{2}{*}{ Dogs } & Diarrheic (other causes) & 5 & \multirow{2}{*}{13} \\
\hline & Apparently healthy & 8 & \\
\hline \multirow{3}{*}{ Piglets } & Confirmed CDI & 8 & \multirow{3}{*}{16} \\
\hline & Diarrheic (other causes) & 4 & \\
\hline & Apparently healthy & 4 & \\
\hline \multirow{3}{*}{ Foals } & Confirmed CDI & 4 & \multirow{3}{*}{8} \\
\hline & Diarrheic (other causes) & 2 & \\
\hline & Apparently healthy & 2 & \\
\hline Calf & Diarrheic (other causes) & 2 & 2 \\
\hline Ocelot & Confirmed CDI & 1 & 1 \\
\hline Maned wolf & Diarrheic (other causes) & 1 & 1 \\
\hline Human & Confirmed CDI & 13 & 13 \\
\hline Total & & & 54 \\
\hline
\end{tabular}


Table 2 - The MIC in $\mu \mathrm{g} \mathrm{ml}^{-1}$ and antimicrobial susceptibility classification for 54 Clostridium difficile strains isolated from human and animal feces.

\begin{tabular}{|c|c|c|c|c|c|c|c|c|c|c|c|c|c|c|c|}
\hline \multirow{2}{*}{ Antimicrobial } & \multicolumn{12}{|c|}{---------------------Number of strains and $\mathrm{MIC}\left(\mu \mathrm{g} \mathrm{ml}^{-1}\right)$ - } & \multicolumn{3}{|c|}{-----Classification $(\%)-$} \\
\hline & 0.25 & 0.5 & 1 & 2 & 4 & 8 & 16 & 32 & 64 & 128 & 256 & $>256$ & $\mathrm{~S}^{1}$ & $\mathrm{MS}^{2}$ & $\mathrm{R}^{3}$ \\
\hline Metronidazole & 20 & 30 & 3 & 1 & & & & & & & & & 100 & 0 & 0 \\
\hline Vancomycin & 28 & 19 & 7 & & & & & & & & & & 100 & 0 & 0 \\
\hline Florfenicol & & & 10 & 42 & & 2 & & & & & & & 96.3 & 3.7 & 0 \\
\hline Oxytetracycline & 34 & 7 & & & & 2 & 6 & & & & & 5 & 79.6 & 11.1 & 9.3 \\
\hline Penicillin & 3 & 24 & 22 & 5 & & & & & & & & & 50.0 & 40.7 & 9.3 \\
\hline Tylosin & 7 & 29 & 1 & 1 & 1 & & 1 & & & 3 & & 11 & 72.2 & 1.9 & 25.9 \\
\hline Erythromycin & 13 & 10 & 7 & 4 & & & 2 & & & 2 & 4 & 12 & 63.0 & 0 & 37.0 \\
\hline
\end{tabular}

Legend: $\mathrm{S}^{1}$ : susceptible, $\mathrm{MS}^{2}$ : moderately susceptible. $\mathrm{R}^{3}$ : resistant (R). Classification based on the CLSI (2011) and EUCAST (2011).

in humans, horses and dogs (BÅVERUD, 2002; MARKS \& KATHER, 2003; BÅVERUD, 2004; SPIGAGLIA et al., 2011; SILVA et al., 2013c). These results are similar to previous studies for several domestic animal species (BÅVERUD et al., 2003; MARKS \& KATHER, 2003; POST \& SONGER, 2004; FRY et al., 2012). Currently, metronidazoleresistant strains have only been isolated from horses in the USA (JANG et al., 1997; MAGDESIAN et al., 2006). Similar to observations in animals, metronidazole-resistant $C$. difficile strains are rarely isolated from humans (SHAH et al., 2010; SPIGAGLIA et al., 2011).

Vancomycin-resistant $\boldsymbol{C}$. difficile isolates are also extremely rare for both animal and human strains. In addition, vancomycin is considered clinically more effective and generates fewer relapse cases following CDI treatment in humans (SHAH et al., 2010); therefore, it is considered the best option by many clinicians. In addition to this study, only one other study in Brazil has evaluated antimicrobial susceptibility in six $C$. difficile strains isolated from humans with CDI; similar to this study, the isolates were also susceptible to metronidazole and vancomycin (BALASSIANO et al., 2009).

None of the strains were resistant to florfenicol, whereas five isolates $(9.3 \%$ ) (two pig isolates, two human isolates and one ocelot isolate) were resistant to oxytetracycline. In general, a large variation in the MIC values were observed for tetracycline, what has also been reported in studies with $C$. difficile strains isolated from pigs and humans (DELMÉE \& AVESANI, 1988; POST \& SONGER, 2004; SHAH et al., 2010). However, almost all isolates from the earlier studies were susceptible to this antimicrobial. Resistance to this class of antimicrobials is commonly associated with the tet genes, especially tetM (HUANG et al., 2009). The high susceptibility of $\boldsymbol{C}$. difficile to tetracyclines differs from other Clostridium species, especially for C. perfringens, which is a species commonly resistant to tetracycline (SLAVIĆ et al., 2011).

The five penicillin-resistant strains were isolated from three foals, all of which had a confirmed CDI diagnosis, and two piglets. Interestingly, in two of the foals, the diarrhea caused by $\boldsymbol{C}$. difficile began after penicillin $G$ was administered under suspicion of pneumonia (SILVA et al., 2012). This result is consistent with observations by BÅVERUD (2002), who reported that beta-lactams are commonly associated with CDI in foals and adult horses. In contrast to reports in other countries (HUANG et al., 2009, SHAH et al., 2010), none of the human isolates were resistant to penicillin in this study, and only one of the 13 strains tested (7.7\%) was moderately susceptible to this compound.

In this study, most strains were resistant to the macrolides erythromycin and tylosin. Detection of $\boldsymbol{C}$. difficile resistance to these compounds was previously reported in strains from various sources, including equine and human isolates (DELMÉE \& AVESANI, 1988; BÅVERUD et al., 2003; SPIGAGLIA et al., 2011). In this study, of the 20 (37\%) erythromycin-resistant strains, ten (18.5\%) were isolated from piglets, four $(7.4 \%)$ from dogs, three $(5.6 \%)$ from humans, two $(3.7 \%)$ from horses and one (1.9\%) from a calf. Of these isolates, $16(80 \%)$ had an MIC greater than or equal to $256.0 \mu \mathrm{g} \mathrm{mL}^{-1}$. In humans, certain macrolides are listed as antimicrobials commonly involved in CDI cases (ZILBERBERG \& SHORR, 2013). Unfortunately, few studies have examined strains from animals, but erythromycin has been reported as a major cause of colitis in mares (BÅVERUD, 2002). Interestingly, the erythromycin- 
resistant $\boldsymbol{C}$. difficile strains isolated from humans vary greatly between countries, with reports ranging from $87 \%$ of isolates with resistance in England to $0 \%$ in Switzerland (HUANG et al., 2009).

The striking bimodal behavior of these isolates for erythromycin resistance suggests a genetic factor that encodes resistance. In fact, studies have shown that the resistance of Clostridium strains to this antimicrobial is primarily related to the erythromycin ribosomal methylase (erm) genes, which encode a methylase that inhibits erythromycin activity (SLAVIĆ et al., 2011). Studies that have examined antimicrobialresistance genes are rare for $\boldsymbol{C}$. difficile strains isolated from animals. However, FRY et al. (2012) recently reported a high correlation between erythromycin resistance and the ermB gene in C. difficile strains isolated from pigs, which confirms this hypothesis. Notably, however, not all strains with high levels of erythromycin resistance encode the erm genes, suggesting that there are other unknown mechanisms involved in resistance (HUANG et al., 2009).

Certain studies have reported high susceptibility of $\boldsymbol{C}$. difficile strains to tylosin, which suggests that this antimicrobial could be used in pig feed to decrease or eliminate $\boldsymbol{C}$. difficile in animal feces (POST \& SONGER, 2004; SONGER \& ANDERSON, 2006). In contrast, 14 strains (25.9\%) in this study were resistant to tylosin; eight were isolated from piglets and three were isolated from dogs, suggesting that this antimicrobial would not be effective for CDI prevention, control or treatment in the species evaluated herein.

Interestingly, tylosin is an antimicrobial commonly used in Brazilian pig production, and all the strains included in this study were from farms that reported using tylosin at some stage in the animal life cycle. In contrast, oxytetracycline is a compound that has been banned from animal feed in Brazil since 1998 (BRASIL, 1998). Two oxytetracycline-resistant strains were isolated from two different pigs on the same farm; both pigs had CDI. On the investigated farm, the owner reported using oxytetracycline in animal feed despite the ban.

Six strains (11.1\%) were had high MIC values for three different antimicrobials (tylosin, erythromycin and oxytetracycline); five of the strains were isolated from pigs and one from a human. One of these strains was isolated from a piglet with CDI and was also resistant to penicillin. Antibiotic therapy plays a central role in CDI development, and the risk increases considerably when $\boldsymbol{C}$. difficile is also resistant to the antimicrobial used (OWENS et al., 2008). Considering that CDIs may be zoonotic, this study indicates that antimicrobials must be used rationally, especially in pig production. Moreover, further studies are needed aiming alternative methods to prevent, control and treat CDIs in domestic animals, what would further reduce the need for antimicrobials in these species.

The results from these antimicrobial susceptibility tests should be interpreted with caution because in vitro results do not always reflect the in vivo behavior of the evaluated drug. Furthermore, studies have shown that the majority of $\boldsymbol{C}$. difficile isolates from drug-induced CDI cases in humans were susceptible in vitro to the drug used (DZINK \& BARTLETT, 1980), which suggests that successful treatment depends on both $\boldsymbol{C}$. difficile susceptibility to antimicrobials and other factors related to the microbiota (BÅVERUD, 2002). In any case, because it is not routinely performed, assessing antimicrobial susceptibility of $\boldsymbol{C}$. difficile strains isolated from humans and animals, including the two strains isolated from wild animals, may be useful in treating enteric disorders caused by this agent. This is the first study to evaluate antimicrobial susceptibility in $\boldsymbol{C}$. difficile strains isolated from animals in Brazil and showed the necessity of control measures of CDI in both humans and animals to avoid the spread of multi resistant strains. Additional studies should also include the ribotyping and evaluation of resistance genes for the strains used herein.

\section{ACKNOWLEGMENTS}

Conselho Nacional de Desenvolvimento Científico e Tecnológico (CNPq), Fundação de Amparo à Pesquisa do Estado de Minas Gerais (Fapemig), Coordenação de Aperfeiçoamento de Pessoal de Nível Superior (CAPES), Institutos Nacionais de Ciência e Tecnologia (INCT) and PRPq-UFMG.

\section{REFERENCES}

BALASSIANO, I.T. et al. Characterization of Clostridium difficile strains isolated from immunosuppressed inpatients in a hospital in Rio de Janeiro, Brazil. Anaerobe, v.15, p.6164, 2009. Available from: <http://www.ncbi.nlm.nih.gov/ pubmed/19154793>. Accessed: January $1^{\text {th }}$ of 2014 . doi: $10.1016 / j$. anaerobe.2008.12.007.

BÅVERUD, V. et al. Clostridium difficile: prevalence in horses and environment, and antimicrobial susceptibility. Equine Veterinary Journal, v.35, p.465-71, 2003.

BÅVERUD, V. Clostridium difficile diarrhea: infection control in horses. Veterinary Clinics of North America: Equine Practice, v.20, p.615-630, 2004. Available from: <http://www.ncbi.nlm. nih.gov/pubmed/15519822>. Accessed: January $1^{\text {th }}$ of 2014 . doi: 10.1016/j.cveq.2004.07.005.

BÅVERUD, V. Clostridium difficile infections in animals with special reference to the horse. A review. Veterinary Quarterly 
Journal, v.24, p.203-219, 2002. Available from: <http://www. ncbi.nlm.nih.gov/pubmed/12540137>. Accessed: January $1^{\text {th }}$ of 2014. doi:10.1080/01652176.2002.9695137.

BOJESEN, A.M. et al. Fatal enterocolitis in Asian elephants (Elephas maximus) caused by Clostridium difficile. Veterinary Microbiology, v.116, p.329-335, 2006. Available from: <http:// www.ncbi.nlm.nih.gov/pubmed/16737787>. Accessed: January $1^{\text {th }}$ of 2014 . doi: $10.1016 /$ j.vetmic.2006.04.025.

BRASIL, Ministério da Agricultura e da Reforma Agrária, Portaria n.193, de 12 de Maio de 1998 [BRAZIL, Ministry of Agriculture and Land Reform, ordinance n.193, 12 May 1998].

CLSI (CLINICAL AND LABORATORY STANDARDS INSTITUTE). Performance standards for Antimicrobial Suceptibility Test. Twenty-first Information Supplement v.31, n.1, p.111, 2011.

DELMÉE, M.; AVESANI V. Correlation between serogroup and susceptibility to chloramphenicol, clindamycin, erythromycin, rifampicin and tetracycline among 308 isolates of Clostridium difficile. Journal of Antimicrobial Chemotherapy, v.22, p.325-331, 1988. Available from: <http:/www.ncbi.nlm.nih.gov/ pubmed/3053559>. Accessed: January $1^{\text {th }}$ of 2014. doi: 10.1093/ $\mathrm{jac} / 22.3 .325$.

DZINK, J.; BARTLETT, J.G. In vitro susceptibility of Clostridium difficile isolates from patients with antibiotic-associated diarrhea or colitis. Antimicrobial Agents and Chemotherapy, v.17, p.695-698, 1980. Available from: <http://www.ncbi.nlm.nih.gov/ pubmed/7396460>. Accessed: January $1^{\text {th }}$ of 2014 . doi:10.1128/ AAC.17.4.695.

EUCAST (EUROPEAN COMMITTEE ON ANTIMICROBIAL SUSCEPTIBILITY TESTING). Breakpoint tables for interpretation of MICs and zone diameters. Switzerland, 2011. V.3.1.

FRY, P.R. et al. Antimicrobial resistance, toxinotype, and genotypic profiling of Clostridium difficile isolates of swine origin. Journal of Clinical Microbiology v.50, p.2366-2372, 2012. Available from: $<$ http://www.ncbi.nlm.nih.gov/pubmed/22518873>.Accessed: January $1^{\text {th }}$ of 2014. doi:10.1128/JCM.06581-11.

HOPMAN, N.E. et al. Acquisition of Clostridium difficile by piglets. Veterinary Microbiology, v.149, p.186-192, 2011. Available from: <http://www.ncbi.nlm.nih.gov/pubmed/21111541>. Accessed: January $1^{\text {th }}$ of 2014 . doi:10.1016/j.vetmic.2010.10.013.

HUANG, H. et al. Antimicrobial resistance in Clostridium difficile. International Journal of Antimicrobial Agents, v.34, p.516-522, 2009. Available from: <http://www.ncbi.nlm.nih. gov/pubmed/19828299>. Accessed: January $1^{\text {th }}$ of 2014 . doi: 10.1016/j.ijantimicag.2009.09.012.

JANG, S.S. et al. Antimicrobial susceptibilities of equine isolates of Clostridium difficile and molecular characterization of metronidazole-resistant strains. Clinical Infectious Diseases, v.25 p.266-7, 1997. Available from: <http://www.ncbi.nlm.nih. gov/pubmed/9310701>. Accessed: January $1^{\text {th }}$ of 2014 . doi: $10.1086 / 516235$.

JHUNG, M.A. et al. Toxinotype V Clostridium difficile in humans and food animals. Emerging Infectious Diseases, v.14, p.10391045, 2008. Available from: <http://www.ncbi.nlm.nih.gov/ pubmed/18598622>. Accessed: January $1^{\text {th }}$ of 2014 . doi: $10.3201 /$ eid1407.071641.

MAGDESIAN, K.G. et al. Molecular characterization of Clostridium difficile isolates from horses in an intensive care unit and association of disease severity with strain type. Journal of the American Veterinary Medical Association, v.228, p.751755, 2006. Available from: <http://www.ncbi.nlm.nih.gov/ pubmed/16506942>. Accessed: January $1^{\text {th }}$ of 2014. doi: 10.2460/ javma.228.5.751.

MARKS, S.L.; KATHER, E.J. Antimicrobial susceptibilities of canine Clostridium difficile and Clostridium perfringens isolates to commonly utilized antimicrobial drugs. Veterinary Microbiology, v.94, p.39-45, 2003. Available from: <http://www. ncbi.nlm.nih.gov/pubmed/12742714>. Accessed: January $1^{\text {th }}$ of 2014. doi:10.1016/S0378-1135(03)00061-0.

NORMAN, K.N. et al. Prevalence and genotypic characteristics of Clostridium difficile in a closed and integrated human and swine population. Applied and Environmental Microbiology, v.77, p.5755-5760, 2011. Available from: <http://www.ncbi.nlm.nih. gov/pmc/articles/PMC3165271>. Accessed: January $1^{\text {th }}$ of 2014. doi:10.1128/AEM.05007-11.

OWENS, R.C.Jr. et al. Antimicrobial-associated risk factors for Clostridium difficile infection. Clinical Infectious Diseases, v.46, S19-31, 2008. Available from: <http://www.ncbi.nlm.nih. gov/pubmed/18177218>. Accessed: January 1th of 2014. doi: $10.1086 / 521859$.

POST, K.W., SONGER, J.G. Antimicrobial susceptibility of Clostridium difficile isolated from neonatal pigs with enteritis. Anaerobe, v.10, p.47-50, 2004. Available from: <http://www. ncbi.nlm.nih.gov/pubmed/16701500>. Accessed: January $1^{\text {th }}$ of 2014. doi: 10.1016/j.anaerobe.2004.01.003.

SHAH, D. et al. Clostridium difficile infection: update on emerging antibiotic treatment options and antibiotic resistance. Expert Review of Anti-Infective Therapy, v.8, p.555564, 2010. Available from: <http://www.ncbi.nlm.nih.gov/ pubmed/20455684>. Accessed: January $1^{\text {th }}$ of 2014. doi: 10.1586/ eri.10.28.

SILVA JÚNIOR, M. Recent changes in Clostridium difficile infection. Einstein, v.10, p.105-109, 2012. Available from: <http:/www.ncbi.nlm.nih.gov/pubmed/23045838>. Accessed: January $1^{\text {th }}$ of 2014 . doi: $10.1590 / \mathrm{S} 1679-45082012000100023$.

SILVA, R.O.S. et al. Detection of $\mathrm{A} / \mathrm{B}$ toxin and isolation of Clostridium difficile and Clostridiumperfringens from foals. Equine Veterinary Journal, v.45, p.671-675, 2013c. Available from: $<\mathrm{http} / /$ www.ncbi.nlm.nih.gov/pubmed/23452044>. Accessed: January $1^{\text {th }}$ of 2014. doi: $10.1111 /$ evj.12046.

SILVA, R.O.S. et al. Detection of enterotoxin A and cytotoxin $\mathrm{B}$, and isolation of Clostridium difficile in piglets in Minas Gerais, Brazil. Ciência Rural, v.41 n.8 p.1430-1435, 2011. Available from: <http://www.scielo.br/scielo.php?pid=S0103$84782011005000100 \&$ script $=$ Sci_arttext $>$. Accessed: January $1^{\text {th }}$ of 2014. doi: 10.1590/S0103-84782011005000100.

SILVA, R.O.S. et al. Clostridium difficile infection: main features and occurrence in domestic species in Brazil. Ciência Rural, v.43, p.73-80, 2013a. Available from: <http://www.scielo. br/scielo.php?pid $=$ S0103-84782013000100013\&script $=$ sci_ 
arttext>. Accessed: January $1^{\text {th }}$ of 2014 . doi: 10.1590/S010384782012005000137

SILVA, R.O.S. et al. Clostridium difficile-associated diarrhea in an ocelot (Leopardus pardalis). Anaerobe, v.20, p.8284, 2013b. Available from: <http://www.ncbi.nlm.nih.gov/ pubmed/23467074>. Accessed: January $1^{\text {th }}$ of 2014 . doi: $10.1016 / j$. anaerobe.2013.02.007.

SILVA, R.O.S. et al. First confirmed case of Clostridium difficileassociated diarrhea in foals in Brazil. Ciência Rural, v.42, p.498-500, 2012. Available from: $<$ http://www.scielo.br/scielo.php?script $=$ sci arttext\&pid=S0103-84782012000300018>. Accessed: January $1^{\text {th }}$ of 2014. doi: 10.1590/S0103-84782012000300018.

SILVA, R.O.S. et al. Evaluation of three enzyme immunoassays and toxigenic culture for the diagnosis of Clostridium difficileassociated enteritis in piglets. Journal of Swine Health and Production, v.21, p.261-269, 2013d. Accessed: January $1^{\text {th }}$ of 2014. Avaliable from: <https://www.aasv.org/shap/issues/v21n6/ v21n6p300.html>.

SLAVIĆ D. et al. Antimicrobial susceptibility of Clostridium perfringens isolates of bovine, chicken, porcine, and turkey origin from Ontario. Canadian Journal of Veterinary Research, v.75, p.89-97, 2011

SONGER, J.G. et al. Equine colitis X associated with infection by Clostridium difficile NAP1/027. Journal of Veterinary Diagnostic Investigation, v.21, p.377-380, 2009. Available from: $<$ http://www.ncbi.nlm.nih.gov/pubmed/19407094>. Accessed: January $1^{\text {th }}$ of 2014 . doi: $10.1177 / 104063870902100314$.

SONGER, J.G.; ANDERSON, M.A. Clostridium difficile: an important pathogen of food animals. Anaerobe, v.12, p.1-4, 2006. Available from: <http://www.ncbi.nlm.nih.gov/ pubmed/16701605>. Accessed: January $1^{\text {th }}$ of 2014 . doi: $10.1016 / j$. anaerobe.2005.09.001.

SPIGAGLIA, P. et al. Multidrug resistance in European Clostridium difficile clinical isolates. Journal of Antimicrobial Chemotherapy, v.66, p.2227-2234, 2011. doi: 10.1093/jac/ dkr292.

ZILBERBERG, M.D.; SHORR, A.F. Preventing Clostridium difficile infection in the intensive care unit. Critical Care Clinics, v.29, p.11-18, 2013. Available from: <http://www.ncbi.nlm.nih. gov/pubmed/23182524>. Accessed: January $1^{\text {th }}$ of 2014 . doi: 10.1016/j.ccc.2012.10.006. 